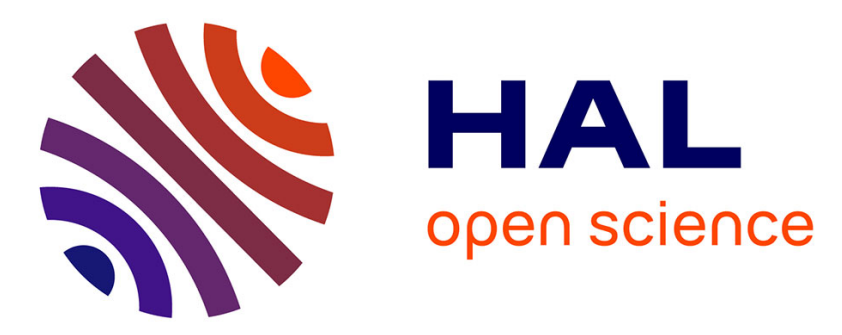

\title{
Recasting Julius Nyerere in Zanzibar: the Revolution, the Union and the Enemy of the Nation
}

\author{
Marie-Aude Fouéré
}

\section{To cite this version:}

Marie-Aude Fouéré. Recasting Julius Nyerere in Zanzibar: the Revolution, the Union and the Enemy of the Nation. Journal of Eastern African Studies, 2014, His Eternity Julius Nyerere? Politics, morality and subjectivities in Tanzania, 10.1080/17531055.2014.918313 . halshs-01493028

\section{HAL Id: halshs-01493028 \\ https://shs.hal.science/halshs-01493028}

Submitted on 12 Apr 2017

HAL is a multi-disciplinary open access archive for the deposit and dissemination of scientific research documents, whether they are published or not. The documents may come from teaching and research institutions in France or abroad, or from public or private research centers.
L'archive ouverte pluridisciplinaire HAL, est destinée au dépôt et à la diffusion de documents scientifiques de niveau recherche, publiés ou non, émanant des établissements d'enseignement et de recherche français ou étrangers, des laboratoires publics ou privés. 


\title{
VERSION BROUILLON PREFINAL
}

\author{
Recasting JuliusNyerereinZanzibar: \\ The Revolution, the Union and the Enemy of the Nation
}

\author{
Marie-Aude Fouéré \\ InstitutFrançais de Recherche en Afrique, Nairobi, Kenya
}

In Zanzibar, the figure of Julius Nyerere is being recast in debates over sovereignty, belonging and nationhood. Unlike mainland Tanzania, where he is upheld as the Father of the Nation, the first President of Tanganyika and Tanzania is increasingly portrayed in Zanzibar as the Enemy of the Nation responsible for the Isles' predicament. The article gives insight into the terms, actors and circulation of this pejorative narrative in relation to two central historical events: the 1964 Revolution and the Union. It also shows how suchanti-Nyererism mediates anxious concerns over cultural distinctiveness and Islam.

Keywords: Nyerere, Nation,Zanzibar, Revolution, Union, Islam.

In present-day Zanzibar, the figure of the first president of Tanganyika (1961-1963) and Tanzania (1964-1985), Julius Kambarage Nyerere, is being recast in collective debates over sovereignty, belonging and nationhood. ${ }^{1}$ Fiery discussions about Zanzibar's self-rule with their array of legalistic arguments about the Union, work migration and borders control, or Zanzibari cultural distinctiveness and civility increasingly conjure up the figure of Nyerere. His political role in the major events that have shaped the history of the archipelago since 1964, as well ashis intentionsand personal sentiments are being explored to speculate about the past and make sense of the present.

If there is no single historical narrative about Nyerere, but on the contrary intertwined stories which local historical debates passionately tangle and disentangle, the opinionthat Nyerere is at the origin of Zanzibar's present-day predicament is a constant theme. ${ }^{2}$ Unlike mainland Tanzania, where he is upheld as the Father of the Nation and made to embody political morality, Nyerere is in Zanzibar increasingly vilified for impoverishing and dividing the population along racial and religious lines through the control of its political elite. As one interlocutor put it during an informal discussion in a café of the capital city Stone Town,"Nyerere is by no means the Father of the Nation(baba wataifa): he is the Enemy of the Nation (aduiwataifa)". Such negative rhetoric about the Enemy of the Nationhas become increasingly widespread since democratization in the mid-1990s. ${ }^{3}$

This article aims to explain the production, dissemination and contemporary uses of this derogatory narrative of Nyerere in Zanzibari. In so doing, it will strive to entwine, in a single argumentation, the terms and tropes of this narrative, its actors and places of production, and its reception and appropriation. Concerning the terms and tropes of this narrative, critical views about Nyerere are especially expressed in relation to two central episodes in the history of the islands through which imaginings of the Zanzibari polity are being articulated today: the Revolution and the Union. Nyerere would have abetted if not masterminded the Revolution of January 1964; he would have engineered the Union between Tanganyika and Zanzibar, which gave birth to the United Republic of Tanzania on 26 April 1964. Both events are cast as strategic means to depriveZanzibar of its sovereignty, and destroythe economy, social fabric, cultural specificity, and religious integrity of the Isles. 
As forthe production and reception of this critical narrative,these categories should not been seen as reflecting impermeable moments or discrete constituencies of people butare partly entangled.Certainly,an array of materials through which such a narrative is being disseminated have been produced by individualauthors since 1964 whosepolitical convictions are known by their readership. Yet, the founding writingsof these "homespun intellectuals" borrow from Derek Peterson, or "amateur historians", whoeach aimedat editing a single story of the role of Nyerere are themselves strongly multi-vocal and characterized by intertextuality. They are re-appropriated by their readers orally through countless mundane streetcorner discussions, formal debates in public forumsor fickle rumours, but also through the written with excerpts reprinted in newspapers or tracts, new publications, and Internet posting.Newhomegrownintellectualsconcerned with their past, whether people of authority in the community or anonymous citizens, therefore enter the stage of this continuous debate over Nyerere,and from readers become producers. Using the language of everyday political discourses, theydo not simply pass on this narrative in its original form, but reshape it, select certain aspects while ignoring others, and add to it other sources of knowledge such as family recounts, popular memories or street stories.

These local architects and brokers of history and memory operate a "compositional work" or assemblage of motifs to create a new product - a process which echoesthe "work of narrative configuration" depicted by Paul Ricoeurwhen, discussing memory narrative, he asserts that "one can always narrate differently, by deleting, by shifting focuses of importance, by re-featuring differently the protagonists of the action at the same time as the contours of the action" 6 . In view of this ongoing "creative writing", 7 it is an illusion to pretend to fully disentangle production and reception.The researcher has to work with acomposite or hybrid narrativemade of multiple intertwined strands ofcollective memories, rumours, individual remembrance, memoirs and autobiographies, conspiracy theories, political and historical amateur essays, and academic works of history. These materials, both oral and print,sometimes visual, are not tobe explored asmere "literary topoi", but must be "anchored in the process of their production, in the orbits of connection that give them life and force" if one aims at producing a heuristic analysis ${ }^{8}$.

Suchgrowinganti-Nyerere views must be explained by taking into account the specificity of the history of the Isles and their relation to mainland Tanzania. Although it will hint at some aspects of political economyand demographic history, this study situates within the framework of the history of ideas in contemporary Zanzibar. It therefore focuses on the circulation of vernacularhistorical knowledge and how such knowledge mirrorspreoccupations typical of the time of its composition. Moreover, the objective of this article is not to assess the adequacy between critical discourses on Nyerere and historical reality, or to measure the veracity of the rewriting of history;it explores how such discourses operate in the present, or to put it differently, how they conceptualize the political space and aim to act upon it by opening a dialogue between the past and the present. How thenegative narrative of Nyerere is deployed, in what circumstances is it used, what claims people make of it and how it contributes to defining certain conceptions of Zanzibarinessconsequently matters more than drawing the line between the historically veridical and the fictional.

It will be shown that the figure of Nyerere works as a negative "place of memory" mostly pioneered by the patriotichomegrownliterati of the Isles and relayed through various political and cultural brokers. This is why we can definethisnegative narrative of Nyerere as a "politicized historical memory": ${ }^{10}$ deployed in the political arena when its promoters seek to influence competition for power, it relates in fine to a sense of collective belonging, whether shared or contested, deeply anchored in specific representations of the past. 


\section{The Zanzibari exception in Tanzania}

Unlike many African countries where fathers of the nation have been challenged or debunked, Tanzania still holds in high esteem its former President. In mainland Tanzania, Mwalimu (the teacher), as Nyerere was affectionately called, is upheld as a genuinely wise and well-intentioned political leader. Since he died on 14October 1999, he has beenset up on a pedestal, embodying an array of moral principles - humility, integrity and incorruptibility variously mobilized by the state, politicians and ordinary citizens in contemporary political and social struggles. The repertoire of values whichTanzania's "Titan" ${ }^{11}$ now symbolizes is appropriated to defineand construct conceptions of political morality and Tanzanianness. ${ }^{12}$ The prominent presence of the idealized figure of Nyerere in the public space does not entail, however, that there is no alternative perspective. Among such alternative narratives, one can find the derogatory rhetoric about Nyerere expressed in Zanzibar, which makes him a central figure albeit in a negative way.

Certainly, the full pervasiveness of this pejorative discourse of Nyerere should not be taken for granted. A brief sociological overview attests to the fact that several factors must be considered in order to understand in which specific circles or networks such derogatory statements are more likely to be heard, as well as variations in the tropes used to express it. Three main factors are underlined here: political affiliations, identity positioning, and religion. Firstly, party affiliations strongly matter, with a strong division between members of the former single party still in power under the name of Chama Cha Mapinduzi (Party of the Revolution, CCM), and the main opposition party in the islands, Civic United Front (CUF). Secondly, identity positioning, primarily cast along ethnic or racial lines, but also between people from Unguja and people from Pemba, also informs reception of the derogatory narrative about Nyerere. Such identity positioning only partly superimposes political loyalties. Thirdly, religious fervour can prompt adherence to this narrative, notably among Muslim activists committed to the propagation of Islam.

However, ethnographic materialsderived from fieldworkconducted in different periods between 2008and 2013 and within a large array of social groups testify that the mainland's iconic image of Nyerere is strongly opposed today not only among the urban Zanzibari activists of the opposition parties and their ordinary sympathizers but are increasingly heard among the many disappointed supporters of the ruling party, whether they continue to vote for this party or not. These opinions are widespread not only among the CUF intelligentsia but also within CCM, from the educated to the common man, and are expressed by journalists and independent intellectuals who claim their free speech and independence from any political party. In spite of the limitation of the research that targeted moretowndwellers than villagers, more CUF hard-line supporters that CCMpartisans, more menthanwomen, more educated than illiterate, we contend that the negative version originally pioneered by nationalistor separatist patriots has become if not fully ubiquitous, at least increasingly visible in the public space in contemporary Zanzibari society, thus leaving little room for thepublic expression of more positive statements. This construction has become a tool for political mobilization. Consequently, the figure of Nyerere is set in a discursive configuration whose understanding is inseparable from a political and social strategy. The politically committed Zanzibari community in diaspora, the educated of the opposition in Zanzibar and Muslim activists play a fundamental role in disseminating it.

It is notable that, in the portrayal of Nyerere as an Enemy of the Nation,the term 'nation' does not refer to Tanzania as a whole but to Zanzibar only, though the Isles are not sovereign. Since 26 April 1964, the date of the passing of the Treaty of the Union between the Republic of Tanganyika and the People's Republic of Zanzibar, Zanzibar has only had a semi-autonomous ${ }^{13}$ status within the United Republic of Tanzania. Yetsuch institutional 
statushas been highly controversial since the establishment of the Union on the ground of entangled arguments. These controversies refer to the two main conceptions of the nation, or nationalisms, in the islands: African nationalism and Zanzibari nationalism. ${ }^{14}$ By nationalism, we do not just mean state ideology or political mobilization by the state, but any dynamics, be they organized or spontaneous, elitist or popular, ordinary or extraordinary, which asserts the existence of a national entity imbued with a sense of collective belonging. ${ }^{15}$

Such nationalisms, expressed along political, cultural and racial lines, are strongly rooted in the long-term history of Zanzibar. In the $19^{\text {th }}$ century, this island world was the centre a powerful commercial empire, under a Sultan, whose economy was mainly based on trade (spices, ivory, and slaves) throughout the Western Indian Ocean, and its creolized population the result of incessant migration from Africa, the Arabian Peninsula, India and the Indian Ocean islands. Today's grievances against the mainland, which the angryrhetoricagainst Nyerere mediates, owe to the present situation characterized by growing disenchantment in the face of unfulfilled promises of self-rule and economic development within the Union - a reality thatappears even bitterer in the face of this revisited past golden age. ${ }^{16}$ The well-known and oft-repeated saying that "when the pipes are played on Zanzibar, all Africa east of the Lakes must dance" was heard again and again during fieldwork. ${ }^{17}$

Last, although Nyerere-bashing is mostly expressed in the realm of politics, it is backed up with arguments of a cultural order that, among others, target Nyerere's use of Swahili language. Supporters of the representation of Nyerere as an enemy of the Zanzibari nation often assert that Nyerere tortured Swahili because he did not speak Zanzibari Swahili, characterized by its Arab borrowings, but mainland Swahili. ${ }^{18}$ For instance, one interlocutor mentioned that Nyerere introduced words taken up from ethnic languages of the mainland. He declared that nobody had ever heard the term kung'atuka before Nyerere used it in 1985 to announce his withdrawal from office, saying "I am leaving (ninang'atuka) power but I still believe that without a strong CCM, our country will falter". ${ }^{19}$ Because language is a marker of identity mobilized to define national belonging and citizenship, anti-Nyererism serves representations of coastal chauvinism and cultural distinctiveness promoted by the Isles' educated patriots, which resonates with "the geography of ethnic difference" built upon a religious and cultural paradigm that distinguishes between the civilized Muslim nobility of the Coast (wastaarabu) and the barbarian unbelievers of the mainland (washenzi). ${ }^{20}$

\section{Revisitingthe 1964 Revolution}

The historical episode recorded in state history and official discourses as the 1964 Revolution refers to the overthrow, on the night of 11-12 January 1964, of the constitutional monarchy of Zanzibar, just one month after it gained independence from the authorities of the British protectorate on 10 December $1963 .{ }^{21}$ During that night and in the following days, the insurgents committed significant violence against members of the ousted government, people of Arab origin and other groups considered alien and close to the political power, namely Indians and Comorians. ${ }^{22}$ The actual facts of this armed take-over are still an "enigma" ${ }^{, 23}$ because of the authoritarian nature of the revolutionaryregime. ${ }^{24}$ Opponents and those recalcitrant to the new men in power, under the presidency of AbeidAmaniKarume, were imprisoned or assassinated. Public freedom was harshly restricted,popular social spaces controlled, the flourishing pre-revolutionary press disappeared, and history as a subject banned in school. In other words, public channels of memory and historytransmission were blocked. In this context of memories that were publicly silenced and therefore driven underground, making of the Revolution an open secret muted yet still privately discussed, the state imposed its own single historical version of events through pro-government publications or Swahili novels made required readings in secondary schools. ${ }^{25}$ 
Firstly, according to this account, the said Revolution would have been sustained by a deep ideological conviction articulated by the Afro-Shirazi Party (ASP), the political party formed in the late 1950s that advocated for narrowly defined African nationalism imbued with racialism. Secondly, the Revolution was cast as a popular uprising supported by the Afro-Shirazi'autochthones' of the Isles, demographically the majority. ${ }^{26}$ Finally, the Revolution would have precipitated the overthrow of a tyrannical power supposedly in the hands of 'alien' Omani Arabsby Afro-Shiraziswhowould have been denied their right to sovereignty for centuries - hence its definition as "the logical outcome of centuries of oppression and subjection of the African people"27. In this view, the 1963 monarchy was not a legitimate regime but the continuation of Omani power under the guise of legality. In this historical master-narrative, the independence of the islands is canonically referred to as "false independence" (uhurubandia). The revolutionary regime built its legitimacy to rule on the Revolutioncredentials. Today, in CCM public meetings, the historical reference to the 'Glorious', 'Sacred' or 'Great'Revolutionis still chanted as a slogan (Mapinduzi!'Revolution!)to which the crowd responds in unison:Daima! (Forever!).

It is as a founding Zanzibari myth of the nation, however,that the Revolution is increasingly contested today. Although the CUF decries the decay of the post-revolution period and its corrupt politicians rather than the Revolution as a founding event, otherminor political currents fully contest the legitimacy of the Revolution. Their contest is sustained by the selection of other significant historical moments attached to the past of the Isles. ${ }^{28}$ Rather than the armed take-over of 1964, access to full sovereignty through independence from British ruleand the establishment of an electedgovernment in December 1963 is made the event of foundation of the Zanzibari nation. The adoption of a national flag bearing the image of a clove and the granting of a UN seat are held up as symbols of this internationally recognized sovereignty - whose visual archives are notably put online or on Facebook by activists. ${ }^{29}$ Todays'political commitment of separatist groups in Zanzibar is grounded on the idea that the Isles' independence is the product of a century of slow maturation, throughout the 19th century, of a body politic rooted in a clearly delimited island territory.

The nature of the authority of thepre-independence Sultanate is redefined accordingly. Far from being a foreign and colonizing power, the pre-revolutionary regime is granted the status of a legitimate autochthonous power. Culturally, Zanzibar, seen as the cradle of Swahili culture ${ }^{30}$ is defined as a cosmopolitan and mixed-blood society united by a single language, Swahili, and the practice of Islam. ${ }^{31}$ In short, Zanzibari nationalism is deployed in the face of African nationalism that animated the revolutionaries and whose traces still permeates today's official ideology. SuchZanzibari nationalism asserts itself on the basis of historical, political, cultural and religious references associated with a real or imagined Arabnessfrom which today's Zanzibariness would be derived, and which is stronglypermeated with the local deep-rooted "racial thought" developed on the Isles. ${ }^{32}$

\section{Nyerere, mastermind of the Revolution?}

Contestation oftheofficial historyof the Revolution also resorts to the rereading of the role Nyerere played during the revolutionary event. Whether Nyerere knew about the armed coup d'etatbefore it occurred remains debated in academic historiography. AccordingtoIssaShivji, "it was not clear if the Tanganyikan leadership knew or was involved in any way. It is conceivable though that by Friday [one day before the overthrow]Hanga or Babu could have informed Kambona or Nyerere or both. ${ }^{\text {33 }}$ However, individual testimonies on the actual involvement of Nyerere in the Revolution and consequentrole in the Isles' loss of autonomyhave circulated in a clandestine way in Zanzibar since 1964, which some academic publications make reference to. ${ }^{34}$ Thegradual diffusion of these testimonies in 
society was operated through the many biographies, memoirs, political essays and rewriting of historyproduced by exiles of the Revolutionsettled in Europe or in the Arabian Peninsula, and circulated among the educated politicized Zanzibaris, notably among the opposition ${ }^{35}$.

The latest work in this array of rewriting of history is a bookby a Zanzibari scholar living abroad, HarithGhassany, entitled Kwaheriukoloni, Kwaheriuhuru! (Goodbye colonization, Goodbye independence!). ${ }^{36}$ It supports the theory of the organisation of the Revolution by Nyerere and his right-hand man, Oscar Kambona. Written in Swahili, the book undeniably targeted a local audience and aimed at intervening in popular political debates. ${ }^{37} \mathrm{It}$ succeeded well in its objectives, being mentioned in most interviews conducted during fieldwork since its publication in July 2010, most specifically among CUF activists or sympathisers but also among the CCM elite - it was said that the then President, son ofAbeidAmaniKarume, had it by his bedside - whether to praise or decry it. ${ }^{38}$ Presenting a collection of personal testimonies never put in print before, it made waves though its core argument is not fundamentally new, being in line with earliernationalist writingsmentioned above. $^{39}$ The author reveals, through the voice of eyewitnesses or actors of the insurrection, that Nyerere plotted the Revolution, sending his loyal henchmen to organize the mobilisation of sisal workers in Tanganyika, in Tanga region, for armed combat, with the help ofsome mainland immigrants settled in Zanzibar. ${ }^{40}$ The book boldly makes a stand in thelocal historical battle: its title ironically suggests that the departure of the British rulersmade way to a new colonizer, Tanganyika, reducing hopes for sovereigntyto nothing. ${ }^{41}$

More recently, independent media also contributed to resurfacing silenced testimonies and disseminating this patriotic version of history. Among them, the first independent Zanzibari weekly newspaper since 1964, Dira ("vision" in Kiswahili), published in 20022003, was a key player. ${ }^{42}$ The article "Nyerere is not an angel" published in the first edition and written by the newspaper's Chief Editor, Ali Mohamed Nabwa, was clearly intended to dismantle the idealised image of Nyerere upheld in mainland Tanzania (picture 1). The author depicts Nyerere as a condescending and disloyal politician who would have resorted to all sorts of intrigues to get to the top of the state. He would have regarded the Arabs of Zanzibar as a colonizing and enslaving power, hence as a power to be hunt down. According to the article, Nyerere masterminded the Revolution in order to impose, on the islands, the Black African culture of the mainland.In this version of history, the Revolution is nothing more than an "invasion", at times even an "ethnic cleansing" or "genocide". This echoes a terminology increasingly in use within nationalist circles in Zanzibar or abroad through which Nyerereis cast as the wily imperialist who extended his empire on Zanzibar, making it a colony to be exploited for the benefit of the mainland.

\section{Nyerere, Colonizer of Zanzibar?}

In the nationalist version of the history of Zanzibar that the anti-Nyerere rhetoric mediates, the first step of the control of the islands, the Revolution, was followed by a second step aimed at ensuring the total submission of Zanzibar: the establishment of the Union betweenTanganyika and Zanzibar one hundred days after the Revolution.At that time, however, the Union was welcome by politicians and the population, for it was seen as a constitutionalarrangement ${ }^{43}$ that could ensure economic and social development in the Isles, as well as a symbol of pan-Africanist endeavours to foster regional unity. As reminded by Jonathon Glassman, "champions of the union in its current form like to depict it as a singular triumph of pan-African solidarity". Yet, over the years, the island populations and the political elite have become increasingly angered by the encroachment of the Union in the internal affairs of Zanzibar, and its critics now "deny the significance of pan-African ideals and instead regard (the union) as the product of a cynical power play imposed by mainland 
politicians". ${ }^{44}$ Today's opponents of the Union or common people dissatisfied with its current state $^{45}$ harshly denunciate the political and economic marginalization of Zanzibar within the United Republic,often resorting to the terms "colonization" or "imperialism" toadamantly describe what they consider as the annexation of the Isles by ex-Tanganyika.

More than any other books, Ali Muhsin's memoirs, Conflict and Harmony in Zanzibar, was repeatedly mentioned during interviews with the literati of the opposition. This author, who was the "de facto leader" 46 of the 1963 December government, condemns the appalling destruction of Zanzibar both by the revolutionary leaders who "stooped lowest to rob their subject", making Zanzibar "the laughing stock of the world", ${ }^{47}$ and by mainland politicians. Nyerere is made responsible for most evils, being even compared to the dictator Hitler: "Nyerere has destroyed everything that he has ever handled. Hitler built then destroyed everything by his mania. But this man [Nyerere] is worse. (...) He has destroyed Zanzibar and all its fine orchards and plantation of clove trees and coconut palms (...)" ${ }^{48}$ Nyerere's famous statement about Zanzibar, "If I could tow that island out into the middle of the Indian Ocean, I'll do it" ${ }^{\prime 49}$ came up again and again during my research to support the argument that Ali Muhsin's opinion was undeniably right. ${ }^{50}$

In this perspective, the history of the Union is againre-read in the light of the role played by itsmain protagonists, the President of Tanganyika and the President of Zanzibar. Nyerere and Karume, beingre-featured through their relational but opposed positioning,respectively embody Tanganyikan imperialism and Zanzibari nationalism. The wrongs of Nyerere would have been to impose the Union onto Karume by force and by guile. The latter, who had establishedhis powerthrough force andfearuntil his assassination in 1972, is described as a politician who, though he wasa charismatic public speaker, waspoorly competent on institutional, legal and administrative issues. A former rugged seaman who hadtravelled a lot, he was indeed barely educated and ill at ease with English. He feared the local educated employed in his government and public administration, considered capable of formulating well-argued critiques or organizing his overthrow. ${ }^{51}$ Seen as political rivals, many among the Zanzibari intelligentsia wereeliminated or forcedinto exilebetween 1964and 1972, for he had"no mercy for his enemies". 52

However, because of his supposedly reluctance to sign the Union Treaty ${ }^{53}$ and efforts to increase the autonomy of Zanzibar during the entire period of his reign, Karume is increasingly upheld as symbol of resistance to what is presented as the insidious annexation of the Isles, as well as for his grand vision for Zanzibar's social and economic development. As IssaShivji asserts, "official historiography repeats ad nauseam that Karume was a Union enthusiast. Nothing could be further from the truth. If there is one thing that Zanzibaris venerate Karume for, in spite of his despotic rule, it is Karume'sZanzibariness and his dogged resistance to get integrated into the Union and loose Zanzibari autonomy." ${ }^{, 54} \mathrm{My}$ interlocutors repeated at will the phrase attributed to Karume that "the Union is like a coat, if it's too tight you can take it off' in order to underscore Karume's contempt for the Union. The other oft-repeated famous line by Karume that "the Arusha Declaration stops at Chumbe", an island at the entry of Zanzibar Town, alsopoints to Karume' resistance to adopt the path of socialist development followed in the mainland. ${ }^{55}$ (picture 2)

Interestingly, Karume's foreign origin, his defence of parochial Africanness as opposed to Zanzibar's cosmopolitan dhow culture, his absence in the night of the Revolution, his authoritarianism and arbitrary power, the deprivation caused by the ban on food imports into the Isles from the late 1960s, the racist invectives that he held against so-called foreigners such as the Asians and Comorians, and finally his lifestyle in conflict with Muslim precepts $^{56}$ - in short, a whole set of elements that are summoned in today's popular discussions- are glossed over when the passing of the Union is debated.Karumeis then portrayed as Nyerere's helpless victim. When the assassination of Karume is recalled, ${ }^{57}$ it is 
much less to remind that it hastened the end of a regime in which "political thuggery was a virtue" ${ }^{, 58}$ than to assert that Nyererewas the one whohad armedKarume'smurderers. It is said that Karume was, at that time, on the point of severing the Union. ${ }^{59}$ Karume's violence and lawlessness, denounced internationally, also constituted a real burden on Nyerere, assuch attitudeswere detrimental to the image of Tanzania on the international scene ${ }^{60}$. Last, it is often recalled, in the talks anddebates of the patriotic intellectuals, that Nyerere was mentioned under the nickname of "Mister X" in the trial of the alleged conspirators of the assassination of Karume. ${ }^{61}$ Undeniably, Nyerere is castigated as the ultimate instigator of this crime andonce againportrayed as ashrewd manipulator.

\section{Ending "Nyerere's dictatorship"}

Current public discussions on the revision of the Constitution of the United Republic of Tanzania - a process launched after the last general electionsof October 2010 - illustrates the pervasiveness of these negative tropes about Nyerere and their use in the political realm. Thisrecent phase of political turmoil actually started in the lead-up to last election, when,in August 2010, the House of Representatives amended the Constitution ofZanzibar and adopted the principle of power sharing between the elected partyand the opposition, which was to be applied after the elections. ${ }^{62}$ This coalition government was expected to end fifteen years of tensions betweenCCM and CUF. ${ }^{63}$ The amendment was also a first symbolic step towards greater autonomy for the Isles because it included the principle that the Isles were a $n c h i$, a Swahili word meaning 'country' but also 'homeland' or 'nation.'

The outraged reactions from the mainland revealed that these constitutional changes were seen as a major threat to the integrity of Tanzania. Several political or legal organizations of the mainland as well as independent lawyers spoke out, saying that such amendmentsneeded to bein accordance to the Constitution of Tanzania. They feared that this thinly veiled claim to sovereignty might lead to the dismantling of Tanzania. In this mainland outcry, the demand for increased autonomy by Zanzibar was vilified as an attack on the memory of the Father of the Nation and a betrayal of the legacy of unity and peace he had left to the country. Nyerere'swell-known political speeches on unity and against parochialism, especially with regards toZanzibar,were again quoted, reprinted and broadcast tochampion the respect of the Union.

Public debates organized in Zanzibar since 2011 also resonated with deep-rooted antiNyererism. Various Zanzibari institutions gathered to launch such public gatherings with the declared aim of countervailing the usual technocratic monopoly on legal and institutional issues. During the months of February and March 2011, the research institute ZIORI (Zanzibar Indian Ocean Research Institute) in partnership with legal organisations (ZLSC, Zanzibar and ZLS Law Services Centre, Zanzibar Law Society) and Muslim organisations such as JUMIKI, commonly referred as Uamsho (JumuiyayaUamshonaMihadharayaKiislamu, the Association for the Awakening and Propagation of Islam)and JUMAZA (JumuiyayaMaimamu Zanzibar, the Association of Imams in Zanzibar) held several meetings, under the umbrella of BAKAZA (Baraza la Katiba Zanzibar, the Zanzibar Constitution Council). Started with speeches by well-known professionals and academics who discussed the legal dimension of the revision of the constitution, they were an opportunity for the public to make their voice heard. The audience was largely made up of activehomespun patriotic intellectuals, readers of the nationalist texts discussed above. Legalistic arguments were relentlessly summoned to remind that the original document of the Union Treaty, which needed to be signed by both parties to be valid, does not exist or that Karume did not sign it. It was also recalled that the agreement was validated neither by members of the government nor by the then Attorney General Wolfgang 
Dourado.Most of the views expressed revisited the history of the formation of the Unionby putting asignificant emphasis on the manipulation of Karume by Nyerere and Nyerere'sanimus towards Zanzibar.

During a meeting held on 5 March 2011, a journalist, former sympathizer of the Marxist partyUmma Partyand also a former team member of the weekly newspaper Dira, took the mike saying how the Union was the result of a secret agreement between two men only, Presidents Nyerere and Karume, which was held against the great political figures of the Zanzibar Government of 1964, even less approved by the people of Zanzibar: "What I would like to say here is that, that day [of the Union] I was with the late AbdallahKassimHanga. And for your information, that day, the Vice President of Zanzibar, KassimAbdallahHanga, was not aware of this Union. (...) I spoke with AbdulrahmanBabu more than a dozen times, and he said that in all the recommendations on the making of the Union, he and other ministers were not involved". ${ }^{64}$ The presumption of a conspiracy organised by Nyerere and assertions that Karume was an incompetent leader clearly sustainedclaims for a popular debateover the revision of the Union Treaty and the Constitution.

In another meeting, held on 9 April 2011 by the government of the islands and intended to collect citizens' views on an initial version of a draft text of the new Constitution, the atmosphere was charged and the crowd chanted in unison "We do not want the Union", before the leader of JUMAZA ripped the draft stating that the "dictatorship of Nyerere" (udiktetawa Nyerere) was over. Stone Town'sbaraza ${ }^{65}$ echoed these heated constitutional debates, especially among CUF sympathizers. As a middle-aged Zanzibari employed in an educational NGO declared to me a few days later while we were sipping a coffee in the CUF stronghold of Jaws Corner, "that is exactly what was needed to be said: this is the end of Nyerere's dictatorship, which has deprived us of our rights since 1964". Zanzibari nationalism, even separatism, unquestionably feeds into the disrepute of Nyerere, the latter being turned intoa scapegoat in the long series of social, political and religious ills faced by the islands since independence.

Since the beginning of 2012, not only the radicalization of JUMIKI/Uamsho's political stand with regard to the Union, but its increasing visibility and popularity among both the urban and rural populations clearly revealed how much the association between Nyerere, as a negative political figure, and the fight for sovereignty in the Isles has become part of Zanzibari common sense. In one of their earliest public sermons of 2012 in the suburbs of Zanzibar Town, Uamsho's leaders declared their political agenda, saying: "The path is very long to claim for the independence of our country. We need patience and cooperation so as to ensure that our islands will be free. The decision is ours, Muslims." "The"colonization" which they claim to be fighting for the sake of sovereignty both resonates, in their politically discourses, withwhat they see as the destructive politics of Nyerere and his heirs, and the subsequent increasing presence of mainlanders, accused of "invading" the islands. ${ }^{67}$ Today's use of anti-Nyererismin the realm of patriotic activism clearly mediates anxious concerns about cultural distinctiveness and religious integrity in Zanzibar.

\section{Nyerere's Crusade against Islam?}

Strict political determinants are undeniably discussed by Zanzibaris when they explorethe role that Nyerere played during the year 1964. The context of the Cold War, during which Americans feared that Zanzibar might become the "Cuba of Africa," often recalled to highlight how the influence of the international superpowers was central in Nyerere's decision to establish the Union. However, it is striking that, in the anti-Nyerere 
rhetoric, the decisions taken at that time by the Head of the State are not simply regarded as political tactics aimed at, for instance, controlling political opposition, muzzling collective protest or retaining power, but are said to be rooted in prejudices and feelings deeply anchored in Nyerere's heart.

Such accounts assert that as a devout Catholic, ${ }^{69}$ Nyerere would have hated Islam; as a native of mainland Africa, he is castigated for his Arab-bashingrelated toArabs' participation in the slave trade and slavery. Nyerere's objective in pushing the Union is said to be to impose a mainland African regime in the Isles but, even more, to fully destroy an economy of transnational trading networks and a culture too Arabicized for his liking based on endless discrimination against the Africans. Thus, Nyerere's role in the history of the islands is, today, questioned along the lines of his supposed hostility to Arabs and, in extension, to Islam. It does so by drawing upon personal anecdotes, puttingthe emphasis on some of Nyerere's words that might raise suspicion, and resorting to the scientific backing of academic literature on religious preference and discrimination during Nyerere regime. A book by the Catholic father John Sivalonabout Christian-Muslims relations and the Tanzanian state is recurrently used as a reference to support this angry Muslim rhetoric ${ }^{70}$. As reminded by Frederick Ludwig, this publication "has often been referred to as supporting the thesis of the suppressors of Islam (in Tanzania), though this was probably not the intention of the author and publisher". ${ }^{71}$

Theidea that Nyerere was animated by his hostilityto Islam gained momentum in 1998 with the publication The Life and Times of Abdulwahid Sykes: The Untold Story of the Muslim Struggle against British Colonialism in Tanganyikaby Mohamed Said. ${ }^{72}$ In this polemical essay, the author revisits the history of nationalism in Tanganyika to capture the essential contribution, yet erased from official history, of acircle of educated Muslims in Dar es Salaam led by the Sykes family. ${ }^{73}$ Hebrings to light how these Muslim townsmen, who were founders of the first nationalist organisation, took Nyerereto the summit of power, for he was then perceived as "a highly educated person with admirable debating skills". ${ }^{74}$ The book depicts how a conspiracy against Islam was set in motion after Nyerere turned against those who co-opted him to favour his fellow Christian politicians.

The theme of Nyerere's animus towards of Islam also gained visibility following the growing expression of politicized Islam in the media. ${ }^{75}$ The press has been akey player in such politically active Islam. Excerpts of Mohamed Said's and HarithGhassany's worksare often reprinted in the pages of the weekly newspaperAn-Nuur, thus giving increased visibilityto the Muslim question in the public space (picture 3). During and after the 2010 election, An-Nuur provided wide coverage of a set of declarations by Muslims of the mainland against what is referred to as the "Christian system" (mfumowaUkristo), accused of dominating Tanzania and discriminatingthe country's Muslims. It recurrently resorted to terms such as contempt (dharau, uonevu), discrimination (ubaguzi), humiliation (dhulma), hatred (chuki) or religious bias (udini) to describe this Christian system. In such politicized Islam, Nyerere embodies anti-Islam almost single-handedly. Given that in Muslim activism, religious affiliation is equated with national identity, Nyerere is portrayed simultaneously as an enemy of Islam and of the Zanzibari nation.

True, there were times when An-Nuur quoted Nyerere's words in positive terms, for example, when it recalledhisdiscourses on the necessity of the struggle against colonial oppression. In its edition of 18-20 January 2011, for instance, an article citedNyerere's "words of wisdom" according to which "the oppressed, if he does not fight his oppressor, will continue to suffer while his oppressor lives comfortably and peacefully"76 to justify that Muslims, identified with the figure of the humiliated and the oppressed, may fight their Christian oppressors. But more than often, it is as a destroyer of Islam and the main actor, with the support of the Catholic Church of Tanzania, of the establishment of "strategies to 
ensure the preferential treatment of Christians and discrimination of Muslims"77 that Nyerere is vilified in such anti-Christian rhetoric of conspiracy. In this politicized Islamic discourse, the canonization process of Nyererelaunched by the Catholic Church of Tanzania since 2006 is interpreted as the reward of the advantages Nyerere granted to the Church in his lifetime and hisfight against the power and spread of Islam. ${ }^{78}$ Today's canonization process is therefore perceived as proof of the existence of the said Christian preferential system.

The 1964 Revolution, which constitutes for the power in place the founding myth of the Zanzibari nation but rather embodies, for various nationalist movements, the beginning of a new era of colonization of the Isles, has fuelled polarized imaginaries of national identity that no collective consensus has yet pacified. Together with the Union, remembered as the final step in Zanzibar's loss of sovereignty, it constitutes a collective "chosen trauma" "incessantly placed at the basis of conceptions of identity, citizenship and nationhood. Among patriotic homegrown intellectuals committed to the Isles' increased autonomy, if not independence, Nyerere-bashingis increasingly mediating local conceptions of Zanzibariness. Althoughgrievances againstNyerere's destructive politics are varied and can be expressedin different ways according to the people, moments and objectives of their mobilisation, the views that Nyerere was the Enemy of the Nation have become a widespread political discourse which is used to negatively define who is a Zanzibari, and to claim for change in the institutional status of the Isles.

From the partisan vantage point of these patriotic homespun historians, Nyerere is broadly cast in the reversed traits of the idealized Zanzibari: he is the invader who came from mainland Africa as opposed to a maritime civilization open to distant horizons; the Christian hateful of Arabs and Muslims ina society that celebrates Arabness and Islam; the ignorant from the African bush as opposed to the island Swahili and Arab highly educated scholars. In this highly pejorative narrative deployed within nationalist circles, victimisation is a manifest and operates at different levels: naïve Karume is the victim of cunningNyerere; the Muslims are the victims of a Christian conspiracy hatched against them; the Arabs are the victims of the bloodthirsty passions of African assassins; and finally the islands of Zanzibar are the victims of the neo-colonial appetites of mainland Tanzania. Given the memory trajectory of Nyerere in mainland Tanzania, characterised by a constant increase in official deference, Zanzibari growing anti-Nyererismvariously fuelled by patriotic discourses therefore stands as an exception.

Certainly, one can still hear respondents admit that Nyerere's influence was beneficial to mainland Tanzania, evoking the formation of a sense of collective belonging on which the cohesion and unity of the people of the mainland would be built today. This sense of belonging is seen as the product of the spread of Swahiliand the weakening of ethnic distinctions in former Tanganyika. In other words, the major themes underlying the official public memory of Nyerere asdisseminated in mainland Tanzania are acknowledged by some Zanzibari critics of Nyerere. Yet they do soonlywhen these themes are applied to the population of mainland Tanzania, not of Zanzibar. In other words, in Zanzibar, the figure of Nyerere can combine the attributes of a baba wataifa with those of an aduiwataifabecause the term taifa refers, in each phrase, to two separate entities: mainland Tanzania on the one hand; Zanzibar in the other. ${ }^{80}$ On islands where the official narrative of the nation is not full shared, the figure of Nyerere works as a negative "place of memory"from which the patriotic literati can pioneer contemporary conceptions ofbelonging and nationhood. 


\section{References}

Amory, Deborah Peters. "The Politics of Identity on Zanzibar." PhD diss., Stanfrod University, 1994.

Anderson, Benedict. Imagined Communities: Reflections on the Origin and Spread of Nationalism. London: Verso, 1983.

Babakerim. The Aftermath of Zanzibar Revolution. Muscat Printing Press (self-published), 1994.

Bailey, Martin. The Union of Tanganyika and Zanzibar: A Study in Political Integration. Syracuse, N.Y.: Syracuse University Press, 1973.

Bakari, Mohammed A. The Democratization Process in Zanzibar: A Retarded Transition. Hamburg: InstitutfürAfrika-Kunde, 2001.

Bakari, Mohammed \&Makulilo, Alexander. "Beyond Polarity in Zanzibar. The 'silent' referendum and the government of national unity." Journal of African Contemporary Studies 30, no. 2(2012): 195-218.

Becker, Felicitas. "Remembering Nyerere: Political Dissent Rhetoric and Dissent in Contemporary Tanzania." African Affairs 112, no. 447 (2013): 238-261.

Bissell, William C. "Engaging Colonial Nostalgia."Cultural Anthropology 20, no. 2 (2005): 215-248.

Burgess, Thomas G. "Cinema, bell bottoms, and miniskirts: Struggles over youth and citizenship in revolutionary Zanzibar." International Journal of African Historical Studies 35 (2002) 2-3: 287-314.

Burgess, Thomas G. "An imagined generation: Umma youth in Nationalist Zanzibar." In In Search of a Nation. Histories of Authority \& Dissidence in Tanzania, ed. Gregory H. Maddox and James L. Giblin, 216-249. Oxford: James Currey Ltd, 2005.

Burgess, Thomas G. "The Young Pioneers and rituals of Citizenship in Revolutionary Zanzibar." Africa Today 51, no. 3 (2005): 3-29.

Burgess, Thomas G. "Memories, Myth and Meanings of the Zanzibari Revolution". In War and Peace in Africa, ed. ToyinFalola and Raphael C. Njoku, 429-450. Durham: Carolina Academic Press, 2010.

Burgess, Thomas G. "Karume the Terrible." In Race, Revolution, and the Struggle for Human Rights in Zanzibar, Thomas G. Burgess,202-209. Ohio: Ohio University Press.

Cameron, Greg. "Narratives of Democracy and Dominance in Zanzibar." In Knowledge, Renewal and Religion. Repositioning and Changing Ideological and Material Circumstances among the Swahili on the East African Coast, ed. Kjersti Larsen, 151-176. Uppsala: NordiskaAfrikainstitutet, 2009.

Caplan, Pat. "'But the Coast, of Course, is Different'. Academic and Local Ideas about the East African Littoral." Journal of Eastern African Studies 1, no. 2 (2007): 305-320.

Caplan, Pat, and Farouk, Topan, ed.Swahili Modernities: Culture, politics and identity on the East Coast of Africa. Trento New Jersey: Africa World Press, 2004.

Chachage, C.L.S. 2004. Environment, Aid and Politics in Zanzibar. Dar es Salaam: Dar es Salaam University Press.

Chachage, Chambi\&Cassam, Annar. Africa's Liberation. The Legacy of Nyerere. Nairobi, Kampala: Pambazuka, Fountain Publishers. 
Chase, H. "The Zanzibar Treason Trial." Review of African Political Economy 6 (1976):1433.

Civille, John R. \&Duggan, William R. Tanzania and Nyerere: A Study of Ujamaa and Nationhood.Maryknoll : Orbis Books, 1976.

Clayton, Anthony. The Zanzibar Revolution and its Aftermath. London: C. Hurst \&Company, 1981.

Fair, Laura. Pastimes and Politics. Culture, Community and Identity in Post-Abolition Urban Zanzibar, 1890-1945. Oxford: James Currey, 2001.

Fairooz, Amani T. Ukwelinihuu (kusutauwongo). Dubai (self-published), 1995.

Fouéré, Marie-Aude (f/c 2014). "Julius Nyerere, Ujamaa and Political Morality in Contemporary Tanzania”, African Studies Review (accepted 14/02/2012).

Fouéré, Marie-Aude. "Reinterpreting revolutionary Zanzibar in the media today: The case ofDira newspaper." Journal of Eastern African Studies6, no. 4 (2012): 672-689.

Fouéré, Marie-Aude. "Remembering the Dark Years (1964-1975) in Zanzibar." Encounters 5 (2012): 113-135.

Fouéré, Marie-Aude. "Tanzanie: la nation à l'épreuve du postsocialisme." PolitiqueAfricaine 121 (2011): 69-85.

Fouéré, Marie-Aude. "Chronique des élections de 2010 à Zanzibar." PolitiqueAfricaine 121 (2011): 127-145.

Gellner, Ernst. Nations and Nationalism. Oxford, Blackwell, 1983.

Ghassany, Harith. KwaheriUkoloni, KwaheriUhuru! Zanzibar naMapinduziyaAfrabia. To check, 2010.

Glassman, Jonathon. "Sorting out the tribes; the creation of racial identities in colonial Zanzibar's newspaper wars." Journal of African History 41 (2000):395-428.

Glassman, Jonathon. "Slower Than a Massacre: The Multiple Sources of Racial Thought in Colonial Africa." The American Historical Review 109, no. 3 (2004): 720-754.

Glassman, Jonathon. War of Words, War of Stones. Racial Thought and Violence in Colonial Zanzibar. Bloomington and Indianapolis: Indiana University Press, 2011.

Harding, Leonhard. "Nyerere in NeuemLicht. Interpretationen in den Lebensgeschichten vonSansibaris." In Unser Lebenvor der Revolution und danachMaishayetukablayaMapinduzinabaadaye.

AutobiographischeDokumentartextesansibarischerZeitzeugen, al-Barwani, Sauda A. Köln: 493-577. KöppeVerlag, 2003.

Hobsbawm, Eric.Nations and Nationalism since 1780: Programme, Myth, Reality. Cambridge: Cambridge University Press, 1990.

Hunter, Helen-Louise. Zanzibar. The Hundred Days Revolution. Santa Barbara: ABC-CLIO, 2010.

Kharusi, Ahmed S. Zanzibar: Africa's first Cuba. A Case Study of the New Colonialism. Richmond: Zanzibar Organisation, 1967.

Lofchie, Michael F. Zanzibar: Background to Revolution. Princeton: Princeton University Press, 1965.

Loimeier, R. "Zanzibar's Geography of Evil: the Moral Discourse of the Ansar al-sunna in Contemporary Zanzibar.” Journal for Islamic Studies 31 (2011): 4-28.

Loimeier, R. "Sit Local, Think Global” Journal for IslamicStudies 27 (2007), 16-39.

Loimeier, R. "Memories of Revolution: ZurDeutungsgeschischteeiner Revolution (Sansibar 
1964)." Afrika Spectrum 41, no. 2 (2006): 175-197.

Ludwig, Frieder. "After Ujamaa: Is religious revivalism a threat to Tanzania's stability?'In Questioning the Secular State: the Worldwide Resurgence of Religionin Politics, ed. D. Westerlund,216-236.London: Hurst \& Co, 1992.

Ludwig, Frieder. Church and State in Tanzania, Aspects of a ChangingRelationships, 19611994. Leiden-BostonKöln: Brill, 1999.

Mapuri, Omar. The 1964 Revolution: Achievements and Prospects. Dar es Salaam: Tema Publishers, 1996.

Martin, Esmond B. Zanzibar: Tradition and Revolution. London: Hamish Hamilton, 1978.

Matheson, Archie. "Maridhiano: Zanzibar's remarkable reconciliation and Government of National Unity." Journal of Eastern African Studies 6, no. 4 (2012): 591-612.

Mazrui, Ali A. "The Titan” of Tanzania: Julius K. Nyerere's Legacy. Binghamton: The Institute of Global Cultural Studies, 2002.

Mesaki, Simeon \&MrishoMalipula, "Julius Nyerere's Influence and Legacy: From a Proponent of Familyhood to a Candidate for Sainthood." International Journal of Sociology and Anthropology 3, no. 3 (2011): 93-100.

Muhsin, Ali al-Barwani. Conflicts and Harmony in Zanzibar, Memoirs. Dubai (selfpublished), 2002.

Mwijage, Ludovick S. The Dark Side of Nyerere's Legacy. London: Adelphi Press, 1996 [1994].

Myers, Garth A. "Narrative Representations of Revolutionary Zanzibar". Journal of Historical Geography 26, no. 3(2000): 429-448.

Myers, Garth A.Verandah of Power. Colonialism and Space in Urban Africa. Syracuse, N.Y.: Syracuse University Press, 2003.

Nora, Pierre. Les lieux de mémoire. I, II, III, Paris: Gallimard, 1997.

Nyerere, Julius Kambarage. JuliasiKaisari, Nairobi: Oxford University Press, 1963.

Nyerere, Julius Kambarage. MabepariwaVenisi, Dar esSalaam: Oxford University Press, 1969.

Nyerere, Julius Kambarage.Freedom and Unity, UhurunaUmoja. A selection from writings and speeches 1952-1965, London: Oxford University Press, 1967

Nyerere, Julius Kambarage.Freedom and Development, UhurunaMaendeleo. A selection from writings andspeeches 1968-1973, Dar es Salaam: Oxford University Press, 1967.

Othman, Haroub, and Chris M. Peter. Zanzibar and the Union Question. Zanzibar: Zanzibar Legal Services Centre, 2006.

Rawlence, Ben. "Briefing: The ZanzibarElection.”African Affairs104, no. 416(2005):515523.

Ricoeur, Paul. La mémoire, l'histoire, l'oubli. Paris: Seuil, 2000.

al-Riyami, Nasser Abdulla, Zanzibar. Personalities and Events (1828-1972), Cairo: Beirut Bookshop, 2012.

Said, Mohamed. The Life and Times of Abdulwahid Sykes: The Untold Story of the Muslim Struggle against British Colonialism in Tanganyika. London: Minerva Press, 1998.

Shivji, Issa G. Pan-Africanism or Pragmatism? Lessons of Tanganyika-Zanzibar Union. Dar es Salaam: MkukinaNyota/Addis Abeba: OSSREA, 2008.

Sivalon, JohnKanisaKatolikinaSiasaya Tanzania Bara 1953-1985, Ndanda: Ndanda Publications, 1992. 
Smith, William E. We must run while they walk. A Portrait of Africa's Julius Nyerere. New York: Random House, 1971.

Werbner, Richard. "Beyond Oblivion: Confronting Memory Crisis." InMemory and the Postcolony: African Anthropology and the Critique of Power, ed. Richard Werbner, 1-17. London: Zed Books, 1998.

Wilson, Amrit. US Foreign Policy and Revolution: The Creation of Tanzania. London: Pluto Press, 1989.

\section{Newspapers}

An-Nuur, "MfumoMkristoung'oke au tugawanemachungu [yaudini]" (Eradicate the Christian system or we share the sufferings [of religious preference]), 18-20 January 2011.

An-Nuur, "UtakatifuwaMwalimu Nyerere unatokananaubaguzi wake" (Mwalimu Nyerere's holiness is the result of his racism), An-Nuur, 21-27 October, 2011.

\section{Internet sources}

"Nyerere against Islam in Zanzibar and Tanganyika", http://victorian.fortunecity.com/portfolio/543/nyerere_and_islam.htm (accesssed04/06/2011)

"Suppressing Dissent. The Crackdown on Muslims in Zanzibar", http://www.ihrc.org.uk/attachments/7772_PROOF01mar12ZanzibarReport.pdf $\quad$ (accessed 04/06/2011).

\footnotetext{
${ }^{1}$ I presented a first version of this paper at the conference "Citizenship, Belonging\&PoliticalCommunity in Africa"organized on 11-12 July 2012 at the British Institute in Eastern Africa (BIEA), Nairobi, Kenya by Emma Hunter from the Centre of African Studies of the University of Cambridge. Many comments and questions made that day have been useful when revising this paper. My deep thanks also go to the two reviewers of the journal for their challenging comments. Last, I am indebted to the French Institute for Research in Africa (IFRA) for its continuous support since 2010.

2 Harding, "Nyerere in NeuemLicht".

${ }^{3}$ Popular perceptionsof Nyerereand the Union have variedover the years. Rather positivein the 1960s, a shiftoccurredin the 1970swhen promises of social and economic development failed to materialize. See for instance Glassman, War of Words, 292-293.

${ }^{4}$ Peterson, Creative Writing.

${ }^{5}$ Peterson, Creative Writing.

${ }^{6}$ Ricoeur, La mémoire, 579 (my translation).

${ }^{7}$ Peterson, Creative Writing.

${ }^{8}$ Comaroff\&Comarrof, "Ethnograpy", 34.

${ }^{9}$ Nora, Les lieux de mémoire.

${ }^{10}$ Werbner, "Beyond Oblivion."

${ }^{11}$ Mazrui, "The Titan" of Tanzania.

12 Askew, "Sung and Unsung", Becker, "Remembering Nyerere", Chachage\&Cassam, "Africa’s Liberation", Fouéré "Julius Nyerere" and Fouéré, "Tanzanie."

${ }^{13}$ Theislands havea government and a House ofRepresentativesin chargeofinternal affairs.

${ }^{14}$ See Glassman, War of Words. Today's nationalisms however only partially meet past trends described by Glassman, which he refers to as "African nationalism" and "civilizational nationalism".

${ }^{15}$ The idea of the nation as understood in Zanzibar since at least the 1950 s combines a territory of defined boundaries, a sovereign polity and a common culture. This resonates with the definition of nationalism by
} 
authors such as Anderson, Imagined Communities; Gellner, Nations and Nationalism; Hobsbawm, Nations and Nationalism.

${ }^{16}$ Bissell, "Engaging Colonial Nostalgia."

${ }^{17}$ Quoted in Smith, Nyerere of Tanzania, 90. A simplified version is more commonly in use: "When the pipes play at Zanzibar, they dance at the lakes."

${ }^{18}$ Contrary to this view, many publications present Nyerere as a promoter of Swahili for the purpose of nation building but also because he was himself a lover of this language. For instance, Nyereretranslated twoplays of Shakespeare into Swahili, JuliusCaesar andThe Merchant of Venice. He also worked onthe translationof the Gospels. He wrotehispolitical writingsandgaveall hispublicpolitical discoursein Swahili.

19 'Ninang'atukalakinininaendeleakuaminibila CCM imaranchiyetuitayumba'. The term kung'atuka made alasting impressionbecauseit isconstantly usedby the CCM when asserting thatit should remainthe political keystone of Tanzania.

${ }^{20}$ Glassman, War of Words, 34-39.

${ }^{21}$ In this constitutional monarchy, inspired by the British system, the Sultan was the head of State but his powers were mostly honorific and advisorial.

${ }^{22}$ The last census before the Revolution, in 1948, gives the racial distribution of the population, counting 264,059 inhabitants: $16.9 \%$ Arabs, 5.8\% Indians, $1.1 \%$ Comorians, and $75.7 \%$ Africans (24\% from the mainland; $74 \%$ native). See Lofchie, Zanzibar,71.

${ }^{23}$ Shivji, Pan-Africanism, 62. As stated by the historian Jonathon Glassamn, "the full story of the revolution has still to be written" (War of Words, 284).

${ }^{24}$ Clayton, The Zanzibar Revolution; Martin, Zanzibar.

${ }^{25}$ Myers, "Narrative Representations".

${ }^{26}$ Populations identified as'Shirazi' claim their ancestors came from the cityof Shirazin Iran. They werethe targetsofattacks by Karumewho did not regarded them as "African". In the early1970s, theywererequired topublicly rejecttheir identity. See Amory, "The Politics of Identity."

${ }^{27}$ Mapuri, The 1964Revolution, 1.

${ }^{28}$ As stated earlier, the political proponentsofa contested versionof the greatnational narrativeare numerous. This explains why only certain elementsof this version arehighlighted according to the interlocutors interviewed.

${ }^{29}$ These visual archives are, among others, footage of the ceremony of independence on 10th December 1963, the Zanzibari delegation to the UN, photographs of the national flag, etc.

${ }^{30}$ On the varying definitions of Swahili identity, see Caplan, "But the Coast."

${ }^{31}$ The possession of these linguistic and religious attributes defines the entry into civilisation (ustaarabu), and distinguishes the civilised/educated (waungwana) from the unbelieving and illiterate savages (washenzi). Former strategies of reclassification, with regard to these cultural, linguistic and religious markers, reflect the influence of this high culture on the definition of Zanzibariness. See Fair, Pastimes.

${ }^{32}$ Glassman, War of Words. On the different narratives about the Revolution, see also Myers, "Narrative Representations" and Loimeier, "Memories of Revolution".

${ }^{33}$ Shivji, Pan-Africanism, 46. KassimAbdallahHanga, an ASP uncompromising leftist intellectual, became the Vice President of Zanzibar after the Revolution. Mohamed AbdulrahmanBabu, leader of the Marxist Umma Party, was made Zanzibar Minister of Foreign Affairs and Trade. Oscar Kambona was, in 1964, the Tanganyika Minister of Foreign Affairs and Defence and the confidant of Nyerere.

${ }^{34}$ See for instance Bakari, The Democratization Process, 104, 105: "a group of plotters was apparently working with the support of Tanganyika"; "some unconfirmed sources suspected that the uprising had been well planned from the mainland".

${ }^{35}$ See Babakerim, The Aftermath;Fairooz, Ukwelinihuu; Muhsin, Conflicts and Harmony in Zanzibar.

${ }^{36}$ Ghassany, KwaheriUkoloni.

${ }^{37}$ Ghassany, KwaheriUkoloni, xiv: “(...)kitabuhichikimeandikwakwalughaya Kiswahili iliwatumiajiwalughahiyowawezekufahamunamnaganihistoriaya Zanzibar ilivyopotoshwanawachangiyekujengaharakatimpya (...)" (this book is written is Swahili language so that the users of this language may understand how much the history of Zanzibar was distorted, and contribute to building a new movement).

${ }^{38}$ The fewbooks that were put on sale in Zanzibar were sold out ina few daysin July2010.They circulatedfrom hand tohand (personal communication).

${ }^{39}$ Ifthebook presents itself as academichistoriography, the veracity of the collected testimoniesisdisputed within academiabut alsoamong theeducated populationof the Isles.

${ }^{40}$ Ghassany, KwaheriUkoloni. See for instance p.65: "Nyerere ndiealokuwaakifanya organisation (mipango) yotenakuwezakuwafanyawatuwapinduweserikaliya Zanzibar. Yeye Nyerere" (It was Nyerere who did all the organisation and made it possible for people to overthrow the government of Zanzibar. Nyerere himself'). See also testimonies in chapters 5 and 6. 
${ }^{41}$ In a similar vein, see also the book by Nasser Abdulla Al Riyami, an Omani of Zanzibar origin, recently translated into English (2012), that cast the Revolution as an "invasion", notably p. 147-148.

${ }^{42}$ Dirawas banned by the state in 2003 , one year only after it was launched, because the newspaper was resurfacing alternative memoriesof the Revolutionand producedcounter-narratives of state historyconsidered a threat to civil order. For more details, see Fouéré, "Reinterpreting revolutionary Zanzibar".

${ }^{43}$ Zanzibarretainsan independent governmentbutcedes tothe Union sovereignaffairssuch as the police, the defence, the interior, foreign affairs and customs.

${ }^{44}$ Glassman, War of Words, 292-294.

${ }^{45}$ Othman \& Peter, Zanzibar and the Union Question; Rawlence, "Briefing."

${ }^{46}$ Glassman, War of Words, 6.

${ }^{47}$ Muhsin, Conflicts and Harmony, 282.

${ }^{48}$ Muhsin, Conflicts and Harmony, 162.

${ }^{49}$ Smith, Nyerere of Tanzania.

${ }^{50}$ In this regard, another biography in mainland Tanzania is also frequently mentioned, The Dark Side of Nyerere by LudovickMwijage. This text about the author's persecution and imprisonment is often cited to support the theory that Nyerere schemed and assassinated to get rid of any form of protest, whether in Zanzibar or on the mainland.

${ }^{51}$ SeeMartin, Zanzibar.

${ }^{52}$ Quoted in Myers, Verandah, 117.

${ }^{53}$ However, Haroub Othman ("The Union", 173) says that "according to Nyerere, Karume immediately agreed to the idea (of a union) and suggested that Nyerere should be the president of such a nation".

${ }^{54}$ Shivji, Pan-Africanism, 123-124.

${ }^{55}$ The Arusha Declaration of 1967 established African socialism, or Ujamaa, as a development path for Tanzania based on the communitarisation of the labour force, collectivisation of the means of production, nationalisation of enterprises and establishment of free public services. Zanzibar followed a somehow different path: the leftleaning social and economic grand vision embraced by Karume was implemented in agriculture, education, housing and health but was only partially accomplished and suffered from authoritarian power.

${ }^{56}$ For a depiction of Karume lifestyle and personality, see notably Burgess, "Karume the Terrible."

${ }^{57}$ Karume was assassinated at the ASP headquarters on 7 April 1972.

58 Othman "The Union", 175.

${ }^{59}$ See Shivji, Pan-Africanism, 123 and Chachage, Environment, Aid and Politics.

60 The case of forced marriages between members of the government and young Arab girls was highly publicised internationally (Martin, Zanzibar, 69-71 and Burgess, Race, Revolution, 205). Amnesty International also mobilised to demand the release of political prisoners and to protest against the use of torture in prisons.

${ }^{61}$ Chase, "The Zanzibar Treason Trial."

${ }^{62}$ Bakari\&Makulilo, "Beyond polarity"; "Matheson, "Maridhiano"; Fouéré, "Chronique".

${ }^{63}$ Sincethe reintroductionof multiparty politics in1992, all electionstook placein adeleterious environment. Electoral fraudculminatedin police and military violence, which, in 2001and 2005, caused between 30 and 60deaths andhundreds of injured. See Rawlence, "Briefing."

${ }^{64} 05 / 03 / 2011$, Ecrotanal building, my translation from my recording of the meeting.

${ }^{65}$ Barazaarestone benchesbuilt along theoutside walls of houses, where people liketosit and chat. Theterm metonymicallyrefers to places of daily sociability. See Loimeier, "Sit Local".

${ }^{66} 04 / 03 / 2012$, KibandaMaiti, my translation frommyrecording of the public sermon.

${ }^{67}$ See their recent pamphlet, MipangoyaKuritadisha Zanzibar, distributed during their 2012 public sermons. Fears of uncontrolled immigration and mainland secret agenda of invasionfeature in Uamsho's discourse since the early 2000s, see Loimeier, "The Geography of Evil".

${ }^{68}$ Wilson, US Foreign Policy; Hunter, Zanzibar; Kharusi, Zanzibar.

${ }^{69}$ It is said that, when he was a student at Makerere University, Nyerere considered becoming a priest but hewas dissuaded to do so by his friend, the White Fathers' priest Richard Walsh. See Ludwig (Church and State, 78, 80 note 5) and Civille\& Duggan (Tanzania and Nyerere, 43).

${ }^{70}$ Sivalon, KanisaKatoliki.

${ }^{71}$ Ludwig, "After Ujamaa", 230.

${ }^{72}$ Said, The Life and Times.

${ }^{73}$ KleistSykesis the founderof the AfricanAssociation, a political movement engaged in the struggle against colonialism. He was the Mayorof Dar esSalaam. His son, AbdulwahidSykes, Secretary General of theDockers Union, tookover from himand foundedTANU.

${ }^{74}$ Said, The Life and Times, 111.

${ }^{75}$ Internetalso contributesstronglyto this dissemination. See "Nyerere against Islam" (04/06/2011) or "Suppressing Dissent" (04/06/2011). 
${ }^{76}$ Anayedhulimiwaasipopambananahuyodhalimu, yeyeataendeleakutesekawakatidhalimuatastarehekwaamani', An-Nuur, "MfumoMkristo", 5.

${ }^{77}$ An-Nuur, "MfumoMkristo", 1.

78 "Utakatifu", An-Nuur. On the canonization process, see notably Mesaki\&Malipula, “Julius Nyerere’s Influence."

${ }^{79}$ Glassman, War of Words.

${ }^{80}$ In this regard, the designation of the territorial entities that make up the Unionposits the speakers on the political spectrum: officially, these two entities are referred to as "Mainland Tanzania" (Tanzania bara) and "Island Tanzania" (Tanzania visiwani), butin Zanzibar, the mainlandis often called"Tanganyika". The use of colonial namessymbolically erases the establishmentof the Union. 